\title{
Electromechanically assisted walking in patients with cerebral palsy: A meta-analysis
}

\author{
Kwonhoi Kima, Sukmin Lee ${ }^{b}$ \\ aTeam of physical therapy, Catholic University Uijeongbu ST Mary's Hosipital, Uijeongbu, Republic of Korea \\ ${ }^{b}$ Department of Physical Therapy, College of Health and Welfare, Sahmyook University, Seoul, Republic of Korea
}

Objective: This review aims to analyze the effects of electromechanically assisted walking in patients with cerebral palsy(CP).

Design: A systematic review and meta-analysis.

Methods: We reviewed systematically using the PRISMA (Preferred Reporting Items for Systematic Reviews and Meta-Analyses) checklist guidelines. The inclusion criteria for this study were all CP patients. The intervention was electromechanically assisted walking. The outcome measures included gait parameters, function, spasticity. Studies excluded from this review were excluded from the review if they were non-English languages and if the study was not published as a full report, and if they were not randomized controlled trials (RCTs) designs. The RevMan 5.4 program was used to evaluate and explain the results. The risk of bias was evaluated independently by two reviewers. The quantitative meta-analysis, including mean differences (MD) and associated standard deviations (SD) from baseline and follow-up assessments, were recorded.

Results: A total of 634 articles were searched. Two hundred eighty-nine duplicate articles were excluded, and 345 of 634 originals were left for selection. Of these 74 papers, 44 were out of topic, and 19 reported no mean or standard deviation values. And one was a non-experimental study. Finally, ten studies were included. All 10 RCTs of electromechanically assisted walking were analyzed. The meta-analysis showed a significant improvement in gait cycle (95\% CI (confidence intervals), 0.09 to 0.19 , I $2=0 \%)$, Gross Motor Function Measure (GMFM) D (95\% CI, 3.27 to 13.17, I2=0\%) and GMFM E (95\% CI, 0.22 to 6.41 , $\mathrm{I} 2=0 \%)$.

Conclusions: Electromechanically assisted training helps in walking in patients with CP.

Key Words: Cerebral palsy, Walking, Meta-analysis, Electromechanical

\section{Introduction}

$\mathrm{CP}$ (Cerebral palsy) is caused by posture disorders in daily life and brain malformation or damage during early development [1]. CP is associated with motor impairment and disability throughout life [2]. CP is accompanied by cognitive, motor, and sensory disorders [3]. Movement disorders are often accompanied by cognitive, sensory, and perceptual deficits and communication [4]. Treatment options include physiotherapy; occupational therapy; hippotherapy; orthotics/casting, and postural management [5]. Appropriate evaluation and treatments can favorably influence prognostic outcomes; thus, several techniques have been developed to evaluate gait function and efficiency [6].

Difficulty with walking is considered the important consequence of CP [7]. Gait speed, stride length, step length, and cadence are important indicators of quality of life and functional mobility [8]. Gait training using the principle of improving neuroplasticity in task-specific training is effective in the rehabilitation process [9]. The gait rehabilitation method in patients with neurological disorders relies on technical devices to induce gait in patients with weight support and emphasizes the

Received: Feb 2, 2021 Revised: Mar 15, 2021 Accepted: Mar 16, 2021

Corresponding author: Sukmin Lee (ORCID https://orcid.org/0000-0002-6062-956X)

Department of Physical Therapy, College of Health and Welfare, Sahmyook University, Cheongnyangni P.O.Box 118 Seoul 130-650 Republic of Korea Tel: (82 for International)-02-3399-1632 Fax: 02-3399-1639 E-mail: leesm@syu.ac.kr

This is an Open-Access article distributed under the terms of the Creative Commons Attribution Non-Commercial License (http://creativecommons.org/licenses/ by-nc/4.0) which permits unrestricted non-commercial use, distribution, and reproduction in any medium, provided the original work is properly cited. Copyright @ 2021 Korean Academy of Physical Therapy Rehabilitation Science 
beneficial role of repetitive exercises [10].

In recent years, robotic systems have been used as part of rehabilitation, developing stance, balance, and movement and promoting cortical reorganization through concentration, control, repetition, and motor learning [11]. The potential benefit of the robotic device is that the robotic walker moves the patient's posture and supports the posture, so there is less risk to users and trainers, and the treatment time can be used more efficiently [12]. There is also robotic equipment, as well as a variety of other mechanical approaches to assisting gait. For example, neuromuscular electrical stimulation (NMES) assisted gait is a development technique that demonstrates its potential as an effective and costeffective treatment for gait disorders in patients with spastic CP [13].

A meta-analysis of robot gait training in patients with cerebral palsy [14] and a systematic review of robotassisted gait training for pediatric gait disorders have been previously reported [15]. However, a meta-analysis of the use of robots and other mechanical assistive approaches has not been reported. This review aims to analyze the effects of electromechanically assisted walking in patients with $\mathrm{CP}$.

\section{Methods}

\section{Selection of Studies}

We reviewed systematically using the PRISMA (Preferred Reporting Items for Systematic Reviews and Meta-Analyses) checklist guidelines [30]. The study was approved by the Research Ethics Committee of Sahmyook University (2-7001793-AB-N-012019082HR). The inclusion criteria for this study were all $\mathrm{CP}$ patients. The intervention used in the study was electromechanically assisted walking. The outcome measures included gait parameters, function, spasticity. Studies excluded from this review were excluded from the review if they were non-English languages and if the study was not published as a full report, and if they were not randomized controlled trials (RCTs) designs.

The protocol has been pre-registered with PROPERO (CRD42020140076). We searched for studies in EMBASE, PubMed, and Cochrane databases. The search was conducted in April 2019. In EMBASE, ('Cerebral palsy') AND ('Robotics' OR 'Automation' OR 'gait' OR 'walking' OR 'locomotion') AND ('randomized controlled trial') PubMed and Cochrane Library CENTRAL databases were made using the MeSH keywords. See the Appendix for a detailed example of search strategies for EMBASE and Cochrane Library CENTRAL databases.

\section{Quality assessment}

The risk of bias was evaluated independently by two reviewers. We independently assessed the risk of bias of individual studies. We assessed by using the Cochrane's Risk of Bias tool (random sequence generation, allocation concealment, blinding of participants and personnel, blinding of outcome assessment, incomplete outcome data, selective reporting, and other forms of bias) [29]. The RevMan 5.4 program was used to evaluate and explain the results.

\section{Data extraction}

We used a search strategy to search and select to include titles and abstracts of studies from additional sources. The deduplication was removed and reviewed concerning the inclusion and exclusion criteria. Two reviewers cross-checked the included studies. The quantitative meta-analysis, including mean differences (MD) and associated standard deviations (SD) from baseline and follow-up assessments, were recorded; any disagreements over study selection and data extraction were discussed by both reviewers.

\section{Data Analysis}

Meta-analysis was performed using the Cochrane Library's RevMan 5.4 program. To evaluate the effect estimates for the selected RCTs, the mean and standard deviation values were. A random-effects model was used. Homogeneity was confirmed with the $\mathrm{I}^{2}$ test. An $\mathrm{I}^{2}$ value of $0 \%$ indicates no heterogeneity, $30-60 \%$ indicates moderate heterogeneity, and $75 \%$ indicates severe heterogeneity[29]. The meta-analysis were gait parameters, MAS (Modified Ashworth Scale), and GMFM (Gross Motor Function Measure) dimensions D and $\mathrm{E}$.

\section{Results}

\section{Study Selection}

A total of 634 articles were searched in the PubMed, EMBASE, and Cochrane databases. Two hundred eighty- 


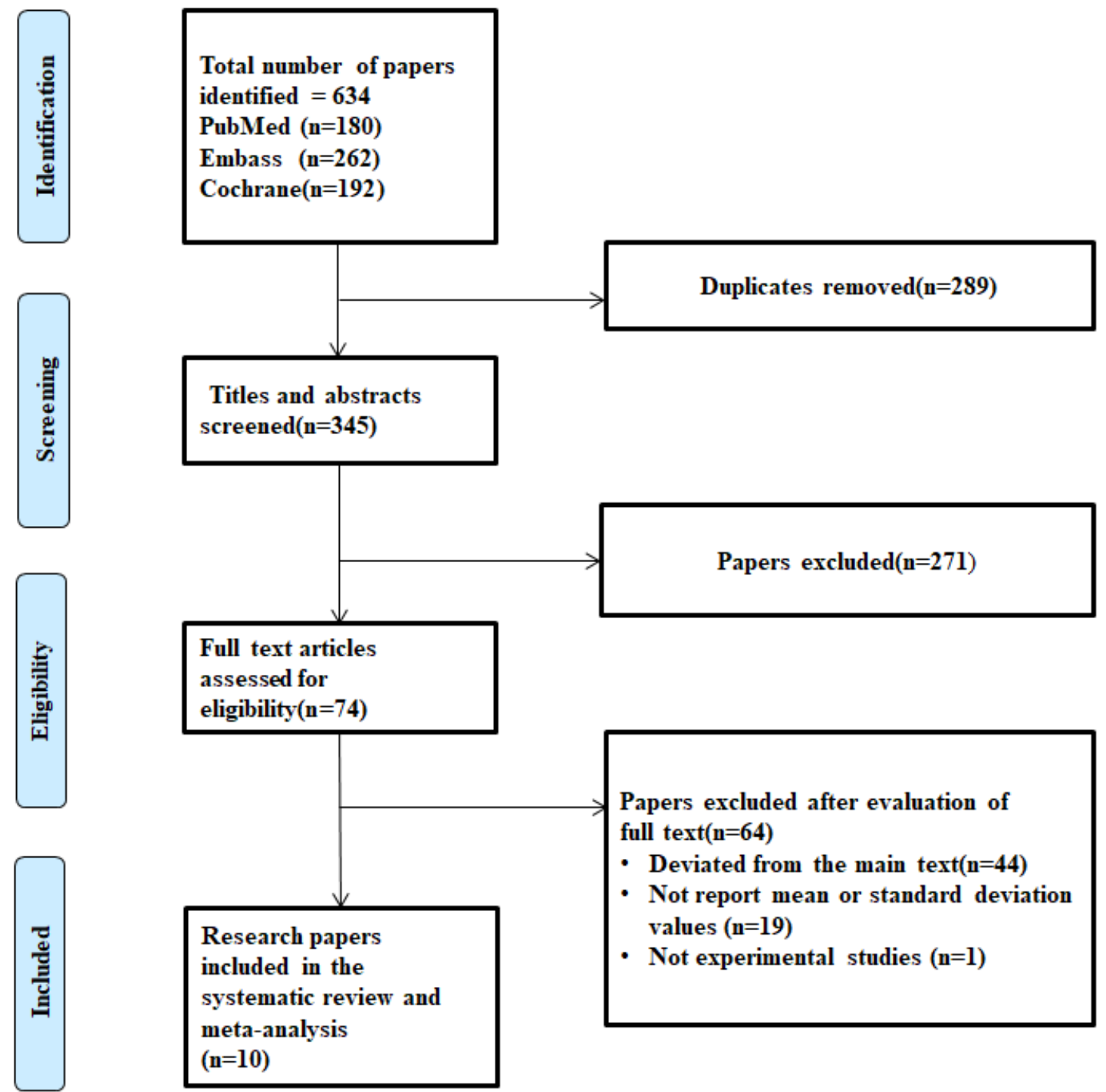

Figure 1. PRISMA flow diagram

nine duplicate articles were excluded, and 345 of 634 originals were left for selection. Of these 74 papers, 44 were out of topic, and 19 reported no mean or standard deviation values. And one was a non-experimental study. Ten studies were finally selected. Ten studies have met all inclusion and exclusion criteria (Figure 1).

\section{Assessment of quality}

In five studies, the allocation concealment was described, and in two papers, blinding of the participants and personnel was considered low. Concerning the blinding of outcome assessment data, two articles were shown to have a high bias. Other biases were shown to have a high degree of bias. All ten studies had a low risk of reporting bias (Figure 2)

\section{Study characteristics}

In this study, all 10 RCTs [17, 19-27] of electromechanically assisted walking were analyzed. The interventions used in the electromechanical device: robotic-assisted treadmill, NMES, Partial body weightsupported treadmill training (PBWSTT), balance-based video games, Transcutaneous Electrical Nerve Stimulation (TENS), Functional Electrical Stimulation (FES), whole-body vibration (WBV), extracorporeal shock wave, and speed-focused elliptical (Table 1). [17, 19-27] 


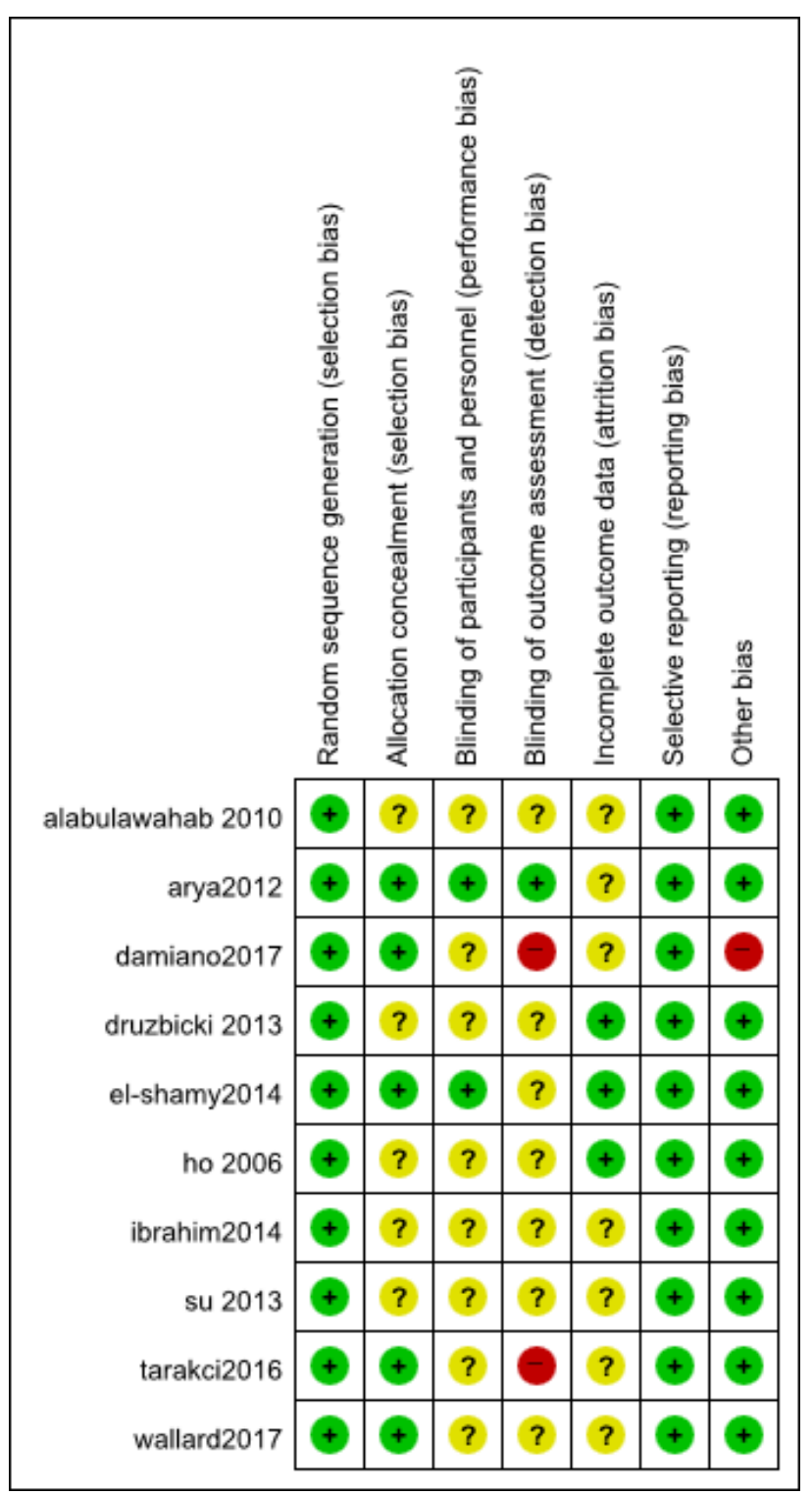

Figure 2. Methodological evaluation

\section{Meta-analysis}

In this study, all 10 RCTs [17, 19-27] of electromechanically assisted walking in patients with cerebral palsy were analyzed.

\section{Gait parameters}

Gait parameters were reported in nine studies. [19-27] For seven parameters, a meta-analysis could be performed The meta-analysis showed a significant improvement in gait cycle (95\% CI, 0.09 to 0.19 , $\mathrm{I}^{2}=0 \%$ ). The meta-analysis showed on walking speed (95\% CI, -0.09 to $0.22, \mathrm{I}^{2}=58 \%$ ), step length $(95 \% \mathrm{CI}$, -2.41 to $\left.6.75, \mathrm{I}^{2}=60 \%\right)$, cadence $(95 \% \mathrm{CI},-22.73$ to $\left.34.61, \mathrm{I}^{2}=82 \%\right)$, Timed Up and Go Test (95\% CI, -1.51 to $\left.3.82, \mathrm{I}^{2}=0 \%\right)$, step width $(95 \% \mathrm{CI},-1.00$ to 1.54 , $\left.\mathrm{I}^{2}=35 \%\right)$, or stride length $(95 \% \mathrm{CI},-0.15$ to 0.38 , $\mathrm{I}^{2}=70 \%$ ) (Figure 3$)$.

\section{GMFM}

The GMFM was reported in three studies [17, 23, 25], with a total of eight different gait parameters. For two dimensions of the GMFM, a meta-analysis could be performed. The meta-analysis revealed significant improvements in GMFM D (95\% CI, 3.27 to 13.17 , $\left.\mathrm{I}^{2}=0 \%\right)$ and GMFM E (95\% CI, 0.22 to $\left.6.41, \mathrm{I}^{2}=0 \%\right)$ (Figure 4).

\section{Spasticity}

Spasticity was reported in two studies. $[24,26]$ The meta-analysis showed in the MAS $\left(p=0.07, I^{2}=0 \%\right)$ (Figure 5).

\section{Discussion}

This review aims to analyze the effects of electromechanically assisted walking in patients with $\mathrm{CP}$ and the first meta-analysis.

One previous meta-analysis analyzed RAGT (robot-assisted gait training) effect on pediatric gait disorders patients. RAGT may help children with gait impairment, especially those with CP [15]. In another meta-analysis, RAGT benefits people with cerebral palsy, specifically by increasing walking ability [14]. However, unlike previous studies, we focused on electromechanically assisted walking, including RAGT, as well as other approaches. A meta-analysis of electromechanically assisted walking following stroke found aid walking [28]. Our results were also shown to aid walking in Electromechanically assisted training.

Walking in cerebral palsy is impaired by the effects of the disease on constant movement and posture [16]. Electromechanically assisted training has great advantages in aiding posture and walking and moves similar to typical walking patterns [17]. To improve walking ability, one can train patients efficiently with repeated electromechanically assisted training. However, electromechanically assisted training needs to walk with equipment, leading to limitations related to cost and locations where the equipment can be used [18]. 
Table 1. Characteristics of Included Studies

$(n=10)$

\begin{tabular}{|c|c|c|c|c|c|}
\hline Study & Sample characteristics & Intervention & $\begin{array}{l}\text { Control } \\
\text { group }\end{array}$ & $\begin{array}{l}\text { Outcomes } \\
\text { (Scale) }\end{array}$ & Results \\
\hline $\begin{array}{l}\mathrm{Su} \text {, et al } \\
\text { China } \\
2013[20]\end{array}$ & $\begin{array}{l}\text { A two period randomized } \\
\text { crossover design consisted of } \\
\text { 12-week PBWSTT }(\mathrm{n}=10) \\
\text { and } 12 \text {-week conventional } \\
\text { gait training }(\mathrm{n}=10)\end{array}$ & $\begin{array}{l}\text { Type: PBWSTT } \\
\text { Format (setting):school } \\
\text { Session: } 2 \text { time/week } \\
25 \text { min for } 12 \text { weeks }\end{array}$ & $\begin{array}{l}\text { Convention } \\
\text { gait training }\end{array}$ & $\begin{array}{l}\text { 1) GMFM } \\
\text { 2) gait speed }\end{array}$ & $\begin{array}{l}\text { 1) Improved } \\
\text { GMFM } \\
\text { 2) Improved } \\
\text { gait speed }\end{array}$ \\
\hline $\begin{array}{l}\text { TARAKCI, } \\
\text { et al, } \\
\text { TURKEY } \\
2016[21]\end{array}$ & $\begin{array}{l}\text { RCT of Nintendo will fit } \\
\text { video game on balance in } \\
\text { children with mild } \mathrm{CP}(\mathrm{n}=15) \\
\text { and NDT and conventional } \\
\text { balance training }(\mathrm{n}=15)\end{array}$ & $\begin{array}{l}\text { Type: Balance Based } \\
\text { Video Games } \\
\text { Format (setting): unclear } \\
\text { Session: } 1 \text { time/week } \\
\text { 50min for } 12 \text { weeks }\end{array}$ & $\begin{array}{l}\text { conventional } \\
\text { balance } \\
\text { training }\end{array}$ & $\begin{array}{l}\text { 1) } \mathrm{TUG} \\
\text { 2) } 10 \mathrm{MWT} \\
\text { 3) } 10 \mathrm{SCT} \\
\text { 4) locomotion }\end{array}$ & $\begin{array}{l}\text { 1) Improved } \\
\text { gait }\end{array}$ \\
\hline $\begin{array}{l}\text { ALAbdulawaha } \\
\text { b, \& Maha } \\
\text { Al-Gabbani } \\
\text { Saudi Arabia } \\
2010 \text { [22] }\end{array}$ & $\begin{array}{l}\text { RCT of conventional TENS } \\
\text { on spasticity in hip adductors } \\
\text { and gait parameters of } \\
\text { children with spastic diplegic } \\
\text { CP }(n=27)\end{array}$ & $\begin{array}{l}\text { Type: TENS } \\
\text { Format (setting):rehabilitation } \\
\text { centers and hospitals } \\
\text { Session: } 15 \mathrm{~min} / \text { session, } \\
\text { 3times a day for one } \\
\text { weeks }\end{array}$ & $\begin{array}{l}\text { conventional } \\
\text { gait training }\end{array}$ & $\begin{array}{l}\text { 1) Step witdth } \\
\text { 2) Step length } \\
\text { 3) Gait speed } \\
\text { 4) MAS }\end{array}$ & $\begin{array}{l}\text { 1) Improved } \\
\text { gait } \\
\text { 2) decreased } \\
\text { spasticity }\end{array}$ \\
\hline $\begin{array}{l}\text { Arya et al., } \\
\text { USA } \\
2012[23]\end{array}$ & $\begin{array}{l}\text { RCT of NMES therapy of } \\
\text { quadriceps femoris and } \\
\text { tibialis anterior muscles on } \\
\text { improving gait and } \\
\text { functional outcomes in } \\
\text { children with } \\
\text { spastic CP }(n=10)\end{array}$ & $\begin{array}{l}\text { Type: NMES } \\
\text { Format (setting): } \\
\text { rehabilitation institute } \\
\text { Session: } 20-30 \mathrm{~min} / \mathrm{session} \\
\text { 4-5 for } 4 \text { weeks }\end{array}$ & $\begin{array}{l}\text { Conventional } \\
\text { muscle } \\
\text { strengthening } \\
\text { exercise }\end{array}$ & $\begin{array}{l}\text { 1) Gait speed } \\
\text { 2) Cadence } \\
\text { 3) Step length } \\
\text { 4) GMFM }\end{array}$ & $\begin{array}{l}\text { 1) Improved } \\
\text { gait } \\
\text { 2) Improved } \\
\text { GMFM }\end{array}$ \\
\hline $\begin{array}{l}\text { Ho et al., } \\
\text { USA } \\
2006[24]\end{array}$ & $\begin{array}{l}\text { RCT of Changes Dynamic } \\
\text { Resources in Children With } \\
\text { Spastic CP }(n=15)\end{array}$ & $\begin{array}{l}\text { Type: FES } \\
\text { Format (setting): } \\
\text { community } \\
\text { Session: } 15 \text { trials }\end{array}$ & $\begin{array}{l}\text { conventional } \\
\text { gait training }\end{array}$ & $\begin{array}{l}\text { 1) Gait speed } \\
\text { 2) Stride length }\end{array}$ & $\begin{array}{l}\text { 1) Improved } \\
\text { gait }\end{array}$ \\
\hline $\begin{array}{l}\text { Ibrahim et al., } \\
\text { Egypt } \\
2014 \text { [25] }\end{array}$ & $\begin{array}{l}\text { RCT of WBV group received } \\
\text { the same program in addition } \\
\text { to WBV training }(n=30) \text { and } \\
\text { physical therapy treatment } \\
\text { program for spastic diplegic } \\
\text { CP }(n=30)\end{array}$ & $\begin{array}{l}\text { Type: WBV } \\
\text { Format (setting): } \\
\text { University } \\
\text { Session: } 60 \mathrm{~min} / \text { session, } \\
3 \text { times/week for } 12 \\
\text { weeks }\end{array}$ & $\begin{array}{l}\text { conventional } \\
\text { gait training }\end{array}$ & $\begin{array}{l}\text { 1) } 6 \mathrm{MWT} \\
\text { 2) } \mathrm{TUG} \\
\text { 3) } \mathrm{MAS}\end{array}$ & $\begin{array}{l}\text { 1) Improved } \\
\text { gait } \\
\text { 2) decreased } \\
\text { spasticity }\end{array}$ \\
\hline $\begin{array}{l}\text { El-Shamy } \\
\text { et al., } \\
\text { Egypt } \\
2014[26]\end{array}$ & $\begin{array}{l}\text { RCT of the effects of shock } \\
\text { wave therapy on gait pattern } \\
\text { in children with hemiplegic } \\
\text { CP }(n=15)\end{array}$ & $\begin{array}{l}\text { Type: Extracorporeal } \\
\text { shock wave therapy } \\
\text { Format (setting): } \\
\text { University } \\
\text { Session: } 3 \text { month }\end{array}$ & $\begin{array}{l}\text { conventional } \\
\text { gait training }\end{array}$ & $\begin{array}{l}\text { 1) Gait speed } \\
\text { 2) Cadence } \\
\text { 3) Stride length } \\
\text { 4) cycle time }\end{array}$ & $\begin{array}{l}\text { 1) Improved } \\
\text { gait }\end{array}$ \\
\hline $\begin{array}{l}\text { Druzbicki } \\
\text { et al., } \\
\text { Poland } \\
2013 \text { [19] }\end{array}$ & $\begin{array}{l}\mathrm{RCT} \text { of study group used } \\
\text { active orthosis in addition to } \\
\text { following a programme of } \\
\text { individual exercises } \\
(\mathrm{n}=26) \text { and control group } \\
\text { participated only in } \\
\text { individual exercises }(n=9)\end{array}$ & $\begin{array}{l}\text { Type: robotic-assisted } \\
\text { treadmill therapy } \\
\text { Format (setting): unclear } \\
\text { Session: } 45 \text { min } 20 \text { session }\end{array}$ & $\begin{array}{l}\text { conventional } \\
\text { balance and } \\
\text { gait training }\end{array}$ & $\begin{array}{l}\text { 1) Gait speed } \\
\text { 2) Step width } \\
\text { 3) cycle time }\end{array}$ & $\begin{array}{l}\text { 1) Improved } \\
\text { gait }\end{array}$ \\
\hline
\end{tabular}


Table 1. Characteristics of Included Studies (Continue)

\begin{tabular}{|c|c|c|c|c|c|}
\hline Study & Sample characteristics & Intervention & Control group & $\begin{array}{l}\text { Outcomes } \\
\text { (Scale) }\end{array}$ & Results \\
\hline $\begin{array}{l}\text { Damiano } \\
\text { et al.,USA } \\
2017 \text { [27] }\end{array}$ & $\begin{array}{l}\text { RCT of Speed-Focused } \\
\text { Elliptical }(n=13) \text { or } \\
\text { Motor-Assisted Cycle } \\
\text { Training }(n=14) \text { in Children } \\
\text { With CP }\end{array}$ & $\begin{array}{l}\text { Type: Speed-Focused } \\
\text { Elliptical } \\
\text { Format (setting): home } \\
\text { Session: } 20 \text { minutes, } 5 \\
\text { days a week for } 12 \text { weeks. }\end{array}$ & $\begin{array}{l}\text { motor-Assisted } \\
\text { cycle trianing }\end{array}$ & $\begin{array}{l}\text { 1) Gait speed } \\
\text { 2) cycle time }\end{array}$ & $\begin{array}{l}\text { 1) Improved } \\
\text { gait }\end{array}$ \\
\hline $\begin{array}{l}\text { Wallard et } \\
\text { al., France } \\
2017 \text { [17] }\end{array}$ & $\begin{array}{l}\text { RCT of RAGT on the } \\
\text { dynamic equilibrium control } \\
\text { during } \\
\text { walking in children with } \\
\mathrm{CP}(\mathrm{n}=14) \text { and receiving } \\
\text { only daily physiotherapy } \\
(\mathrm{n}=16)\end{array}$ & $\begin{array}{l}\text { Type: robotic-assisted } \\
\text { treadmill therapy } \\
\text { Format (setting): hospital } \\
\text { (center) } \\
\text { Session: } 1-20 \\
\text { session/week during } 4 \\
\text { weeks }\end{array}$ & $\begin{array}{l}\text { conventional } \\
\text { balance } \\
\text { training }\end{array}$ & $\begin{array}{l}\text { 1) GMFM } \\
\text { 2) Kinematic } \\
\text { parameter }\end{array}$ & $\begin{array}{l}\text { 1) Improved } \\
\text { GMFM }\end{array}$ \\
\hline
\end{tabular}

CP: cerebral palsy, GMF: gross motor function measure, RAGT: robot-assisted gait training, PBWSTT: partial body weight-supported treadmill training, NDT: neuro-developmental treatment, MAS: modified Ashworth Scale, TUG: timed up and go test, 10MWT: 10 meter walking test, 6MWT: 6 meter walking test, 10SCT: 10 stair climbing test, TENS: transcutaneous electrical nerve stimulation, FES= functional electrical stimulation, WBV: whole-body vibration

Walking speed

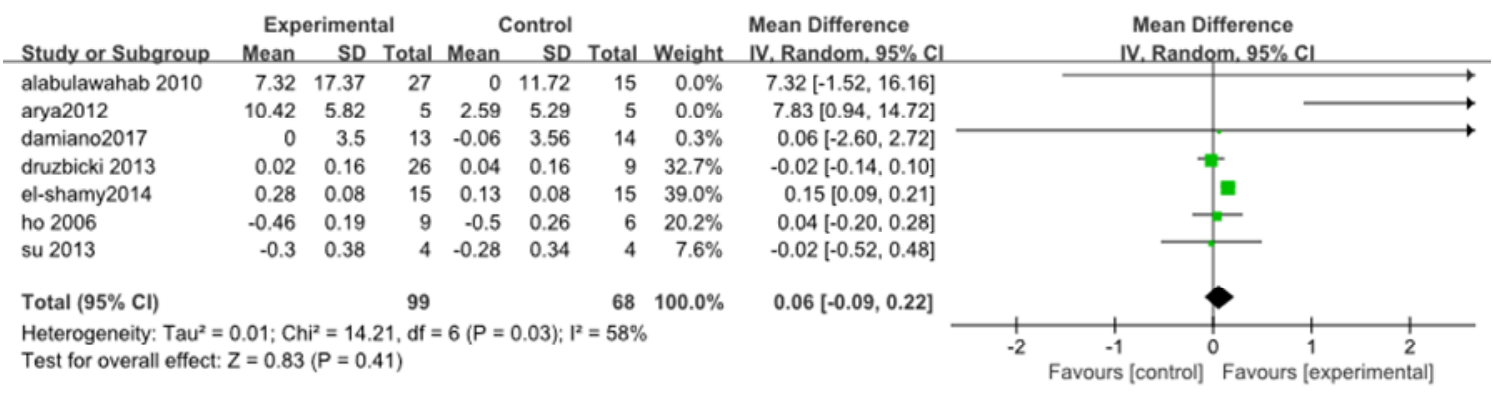

Step length

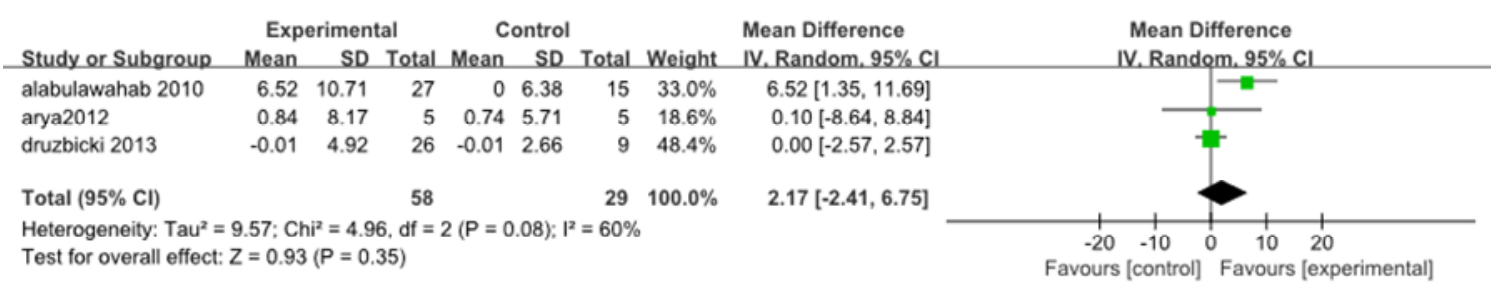

Figure 3-1. Forest plots of the effects on gait parameters 
Cadence

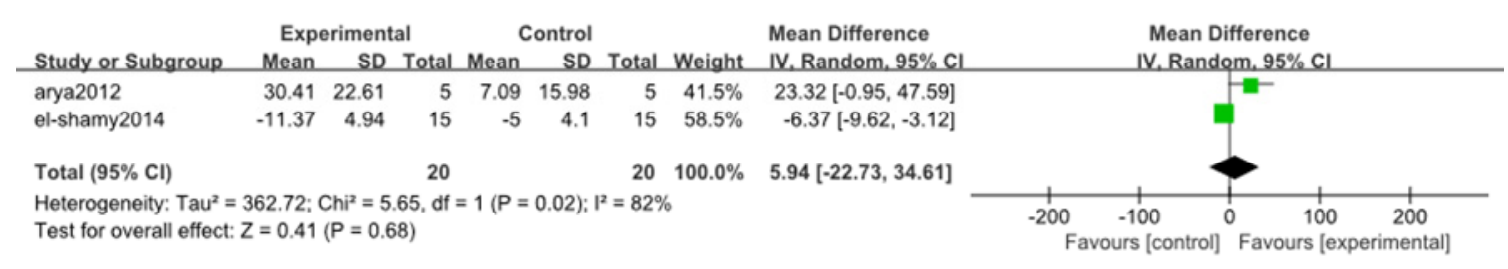

Gait cycle

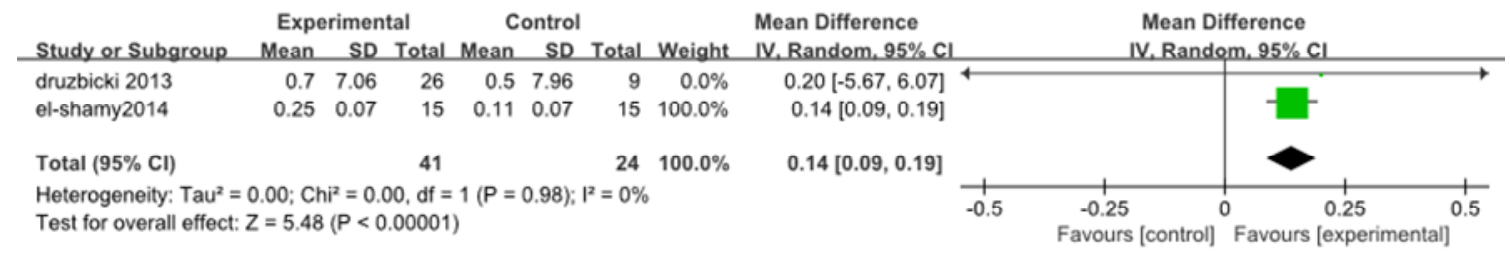

\section{$\underline{\text { TUG }}$}

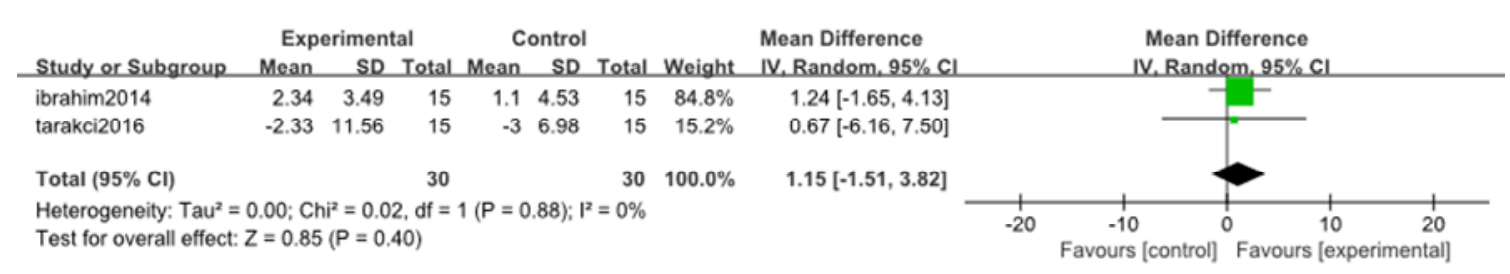

Figure 3-1. Forest plots of the effects on gait parameters (Continue)

$\underline{\text { Step width }}$

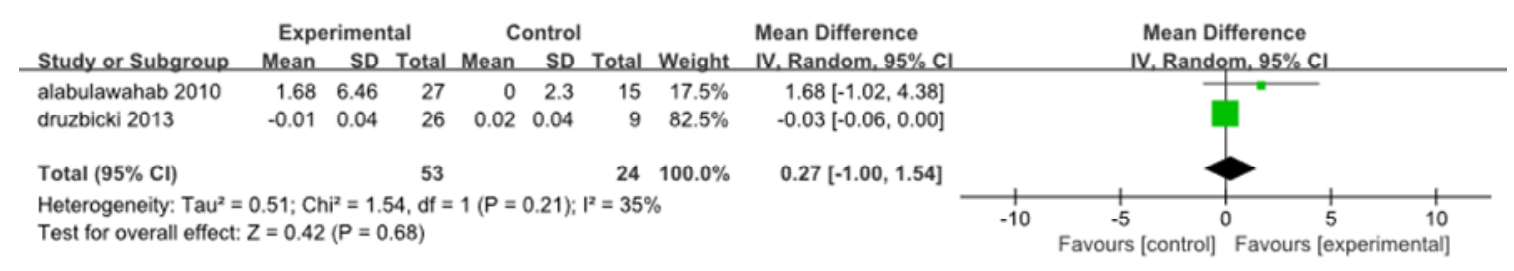

$\underline{\text { Stride length }}$

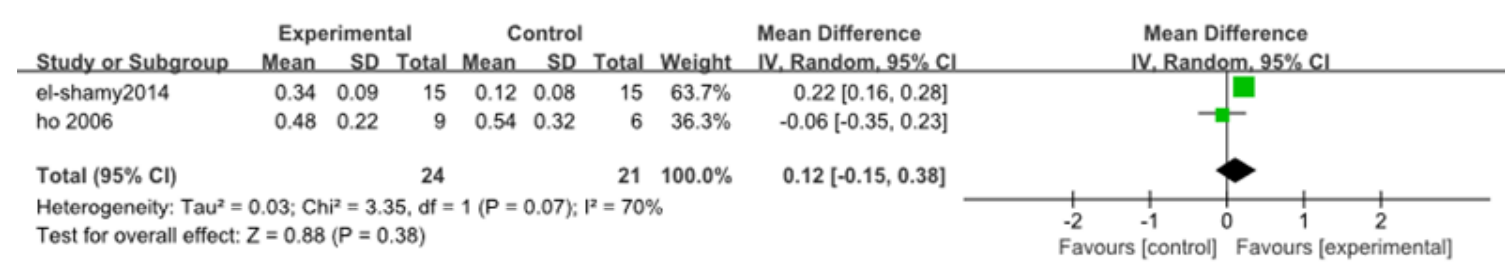

Figure 3-2. Forest plots of the effects on gait parameters 


\section{GMFM D}

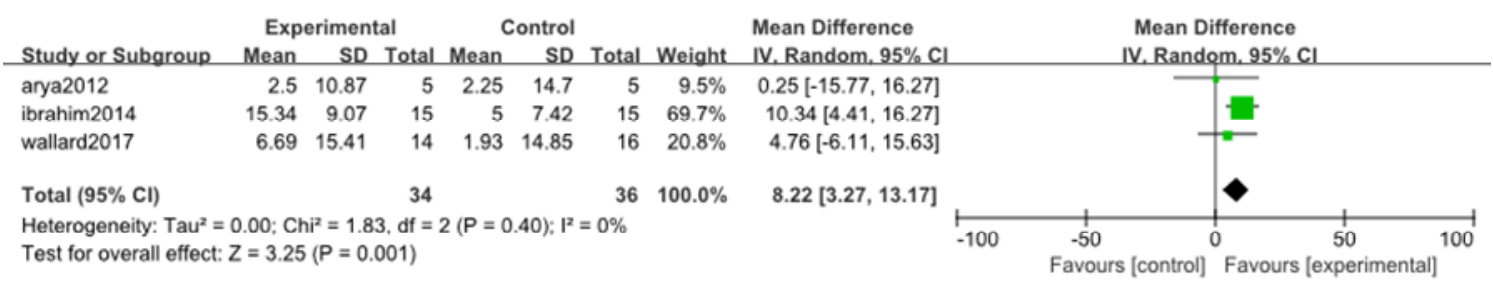

\section{GMFM E}

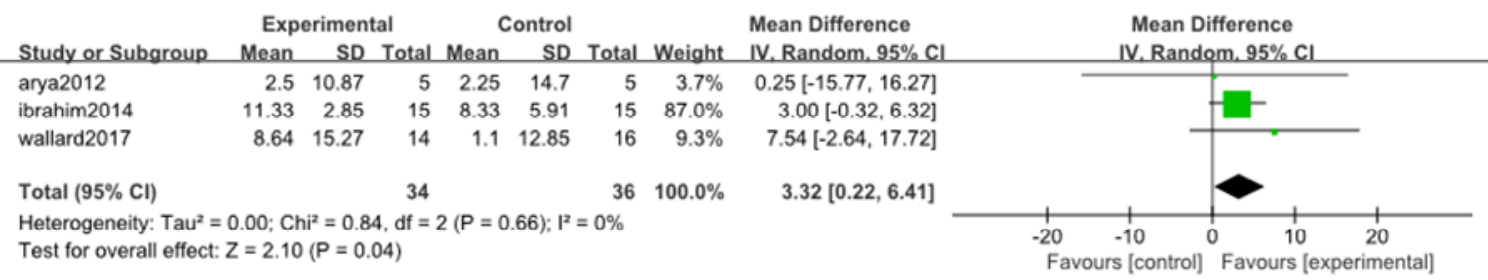

Figure 4. Forest plots of the effects on GMFM

\section{MAS}

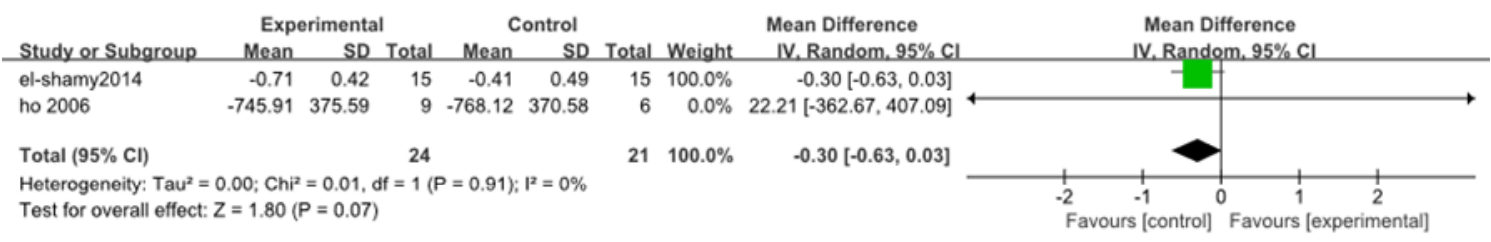

Figure 5. Forest plots of the effects on spasticity

When analyzing the electromechanical gait of the intervention type of the studies, two studies [17, 19] used a robot-assisted treadmill, and eight studies [20-27] examined other machines. In the two selected robotassisted treadmill studies, Lokomat showed improved stability-related metrics [19]. In other studies, the usefulness of the RAGT was mainly related to balance control during gait [17].

Eight studies [20-27] examined other machines to assist gait. In one study, PBWSTT examined the effectiveness of improving gross motor skills. Significant improvements in walking speed have been reported after treadmill training, along with a significantly higher score of total motor function related to walking [20]. Wii-Fit balance-based video games were effective in improving performance-related balance parameters [21]. The use of TENS to hip adductors in CP can improve gait patterns and reduce spasticity [22]. NMES therapy and conventional physiotherapy improve walking ability in cerebral palsy [23]. FES was effective in increasing impulse during walking [24]. WBV improves muscle strength, gait speed, and gross motor performance [25]. Shock wave therapy was effective in improving spasticity and gait pattern [26]. Speed-focused elliptical-Taskspecific effects were equally positive among groups but showed no gait or transfer of functions [27].

We found the effects of electromechanically assisted walking on gait parameters, function, and spasticity in patients with CP. This study improved significantly in the gait cycle and GMFM (D and E). Electromechanically assisted training helps in walking in patients with $\mathrm{CP}$.

The limitation of this review was that the walking aids were analyzed, including the various electromechanicals of cerebral palsy patients, but included studies were small, so the evidence of meta-analysis was weak, and this review was only published in English not 
including various languages. In future studies, included studies should be performed using sufficient size, and a survey of the balance of Electromechanically assisted training is also suggested.

\section{References}

1. Booth ATC, Buizer AI, Meyns P, Oude Lansink ILB, Steenbrink F, van der Krogt MM. The efficacy of functional gait training in children and young adults with cerebral palsy: a systematic review and metaanalysis. Dev Med Child Neurol. 2018;60:866-83.

2. Aisen ML, Kerkovich D, Mast J, Mulroy S, Wren TA, Kay RM, et al. Cerebral palsy: clinical care and neurological rehabilitation. Lancet Neurol. 2011;10:844-52.

3. Baram Y, Lenger R. Gait improvement in patients with cerebral palsy by visual and auditory feedback. Neuromodulation. 2012;15:48-52; discussion

4. Moreau NG, Bodkin AW, Bjornson K, Hobbs A, Soileau M, Lahasky K. Effectiveness of Rehabilitation Interventions to Improve Gait Speed in Children With Cerebral Palsy: Systematic Review and Meta-analysis. Phys Ther. 2016;96:1938-54.

5. Meyer-Heim A, Ammann-Reiffer C, Schmartz A, Schafer J, Sennhauser FH, Heinen F, et al. Improvement of walking abilities after robotic-assisted locomotion training in children with cerebral palsy. Arch Dis Child. 2009;94:615-20.

6. Plasschaert F, Jones K, Forward M. The effect of simulating weight gain on the energy cost of walking in unimpaired children and children with cerebral palsy. Arch Phys Med Rehabil. 2008;89:2302-8.

7. Chakraborty S, Nandy A, Kesar TM. Gait deficits and dynamic stability in children and adolescents with cerebral palsy: A systematic review and meta-analysis. Clin Biomech (Bristol, Avon). 2020;71:11-23.

8. Neto HP, Grecco LA, Duarte NA, Christovao TC, Franco de Oliveira LV, Dumont AJ, et al. Immediate Effect of Postural Insoles on Gait Performance of Children with Cerebral Palsy: Preliminary Randomized Controlled Double-blind Clinical Trial. J Phys Ther Sci. 2014;26:1003-7.

9. Borggraefe I, Schaefer JS, Klaiber M, Dabrowski E, Ammann-Reiffer C, Knecht B, et al. Robotic-as- sisted treadmill therapy improves walking and standing performance in children and adolescents with cerebral palsy. Eur J Paediatr Neurol. 2010;14:496502.

10. Smania N, Bonetti P, Gandolfi M, Cosentino A, Waldner A, Hesse S, et al. Improved gait after repetitive locomotor training in children with cerebral palsy. Am J Phys Med Rehabil. 2011;90:137-49.

11. Yazici M, Livanelioglu A, Gucuyener K, Tekin L, Sumer E, Yakut Y. Effects of robotic rehabilitation on walking and balance in pediatric patients with hemiparetic cerebral palsy. Gait Posture. 2019;70: 397-402.

12. Alazem H, McCormick A, Nicholls SG, Vile E, Adler R, Tibi G. Development of a robotic walker for individuals with cerebral palsy. Disabil Rehabil Assist Technol. 2020;15:643-51.

13. Rose J, Cahill-Rowley K, Butler EE. Artificial Walking Technologies to Improve Gait in Cerebral Palsy: Multichannel Neuromuscular Stimulation. Artif Organs. 2017;41:E233-E9.

14. Carvalho I, Pinto SM, Chagas DDV, Praxedes Dos Santos JL, de Sousa Oliveira T, Batista LA. Robotic Gait Training for Individuals With Cerebral Palsy: A Systematic Review and Meta-Analysis. Arch Phys Med Rehabil. 2017;98:2332-44.

15. Lefmann S, Russo R, Hillier S. The effectiveness of robotic-assisted gait training for paediatric gait disorders: systematic review. J Neuroeng Rehabil. 2017; $14: 1$.

16. Moreno-De-Luca A, Ledbetter DH, Martin CL. Genetic [corrected] insights into the causes and classification of [corrected] cerebral palsies. Lancet Neurol. 2012;11:283-92.

17. Wallard L, Dietrich G, Kerlirzin Y, Bredin J. Robotic-assisted gait training improves walking abilities in diplegic children with cerebral palsy. Eur J Paediatr Neurol. 2017;21:557-64.

18. Grecco LA, Zanon N, Sampaio LM, Oliveira CS. A comparison of treadmill training and overground walking in ambulant children with cerebral palsy: randomized controlled clinical trial. Clin Rehabil. 2013;27:686-96. 
19. Druzbicki M, Rusek W, Snela S, Dudek J, Szczepanik M, Zak E, et al. Functional effects of robotic-assisted locomotor treadmill thearapy in children with cerebral palsy. J Rehabil Med. 2013;45: 358-63.

20. Su IY, Chung KK, Chow DH. Treadmill training with partial body weight support compared with conventional gait training for low-functioning children and adolescents with nonspastic cerebral palsy: a two-period crossover study. Prosthet Orthot Int. 2013;37:445-53.

21. Tarakci D, Ersoz Huseyinsinoglu B, Tarakci E, Razak Ozdincler A. Effects of Nintendo Wii-Fit((R)) video games on balance in children with mild cerebral palsy. Pediatr Int. 2016;58:1042-50.

22. Alabdulwahab SS, Al-Gabbani M. Transcutaneous electrical nerve stimulation of hip adductors improves gait parameters of children with spastic diplegic cerebral palsy. NeuroRehabilitation. 2010;26: 115-22.

23. Arya BK, Mohapatra J, Subramanya K, Prasad H, Kumar R, Mahadevappa M. Surface EMG analysis and changes in gait following electrical stimulation of quadriceps femoris and tibialis anterior in children with spastic cerebral palsy. Annu Int Conf IEEE Eng Med Biol Soc. 2012;2012:5726-9.

24. Ho CL, Holt KG, Saltzman E, Wagenaar RC. Functional electrical stimulation changes dynamic resources in children with spastic cerebral palsy. Phys Ther. 2006;86:987-1000.

25. Ibrahim MM, Eid MA, Moawd SA. Effect of whole-body vibration on muscle strength, spasticity, and motor performance in spastic diplegic cerebral palsy children. The egyptian journal of medical human genetics. 2014;15:173-9.

26. El-Shamy SM, Eid MA, El-Banna MF. Effect of extracorporeal shock wave therapy on gait pattern in hemiplegic cerebral palsy: a randomized controlled trial. Am J Phys Med Rehabil. 2014;93:1065-72.

27. Damiano DL, Stanley CJ, Ohlrich L, Alter KE. Task-Specific and Functional Effects of SpeedFocused Elliptical or Motor-Assisted Cycle Training in Children With Bilateral Cerebral Palsy: Randomized
Clinical Trial. Neurorehabil Neural Repair. 2017;31: 736-45.

28. Mehrholz J, Thomas S, Werner C, Kugler J, Pohl M, Elsner B. Electromechanical-assisted training for walking after stroke. Cochrane Database Syst Rev. 2017;5:CD006185.

29. Higgins JPT, Thomas J, Chandler J, Cumpston M, Li T, Page MJ, et al. Cochrane Handbook for Systematic Reviews of Interventions. 2nd ed. Chichester, UK: John Wiley \& Sons; 2019.

30. Atkins D, Best D, Briss PA, Eccles M, Falck-Ytter Y, Flottorp S, et al. Grading quality of evidence and strength of recommendations. BMJ. 2004;328:1490. 